\title{
A case series of five hypertensive type 2 diabetes patients showing reduction in blood pressure and mean arterial pressure reduction in ambulatory blood pressure monitoring with remogliflozin etabonate $200 \mathrm{mg}$ coprescribed with recent onset anti-hypertensive drugs
}

\section{ABSTRACT}

Introduction. Hypertension is commonly occurring in type 2 diabetes and metabolic syndrome and inflammation are a well-known part of this disease entity. The data of using remogliflozin in Indian patient is not known as this is a very recently approved molecule for the treatment of type 2 diabetes. Here we look into a case series of five patients who had their ambulatory blood pressure monitoring (ABPM) done at baseline and again after 14 days of therapy of adding remogliflozin etabonate to recent onset antihypertensive druges.

Methods. We analysed the ABPM results of five patients after taking their informed consent at baseline and two weeks post-treatment initiation with remogliflozin alongside with recent onset antihypertensive drugs. We used paired $t$ test for statistical analysis of the two readings of each patient to come to a conclusion. Results. We found a statistically significant decrease in mean arterial pressure (MAP) reflected by a $p$ value of

Address for correspondence:

Sayak Roy, MBBS, MRCP

Department of Internal Medicine, Medica Superspeciality Hospital

2/J, Lenin Sarani, Serampore, WB, India. PIN - 712203

Phone: +919051626890

e-mail: sayak.roy.123@gmail.com

Clinical Diabetology 2019, 8, 5, 254-257

DOI: 10.5603/DK.2019.0020

Received: 05.06.2019 Accepted: 25.06.2019
0.0277 and the reduction in mean awake time systolic blood pressure (SBP) was also very close to statistical significance as seen by the $p$ value of 0.0541 . Conclusions. Remogliflozin etabonate when co-prescribed with antihypertensive drugs shows a significant reduction in MAP as well as reduction in SBP although most of the contribution seems to be coming from the antihypertensive molecule itself. (Clin Diabetol 2019; 8, 5: 254-257)

Key words: type 2 diabetes, remogliflozin etabonate, mean arterial pressure, systolic blood pressure, ambulatory blood pressure monitoring

\section{Introduction}

Hypertension is a common entity among diabetic patients, with the prevalence determined by type as well as the duration of diabetes with the other contributing factors being race/ethnicity, sex, age, BMI, presence of kidney disease and glycemic control [1]. A large subset of participants (60\%) in the Avoiding Cardiovascular Events Through Combination Therapy in Patients Living With Systolic Hypertension (ACCOMPLISH) trial were at high risk of cardiovascular events and benazepril plus the dihydropyridine calcium channel blocker amlodipine showed a decrease in morbidity and mortality when compared with the benazepril plus 
Table 1. Baseline characters and drugs used in the case series analysis

\begin{tabular}{|c|c|c|c|c|c|c|c|c|}
\hline $\begin{array}{l}\text { Serial } \\
\text { Number }\end{array}$ & Age & Sex & $\begin{array}{c}\text { Duration } \\
\text { of hypertension }\end{array}$ & $\begin{array}{l}\text { Anti-diabetic } \\
\text { drugs }\end{array}$ & $\begin{array}{l}\text { Duration } \\
\text { of diabetes }\end{array}$ & $\begin{array}{l}\text { Anti-hypertensive } \\
\text { drugs }\end{array}$ & $\begin{array}{c}\text { BMI } \\
{\left[\mathrm{kg} / \mathrm{m}^{2}\right]}\end{array}$ & $\begin{array}{c}\mathrm{HbA}_{1 \mathrm{c}} \\
(\%)\end{array}$ \\
\hline 1 & 62 years & $\mathrm{M}$ & 3 years & 4.5 months & $\begin{array}{l}\text { Metformin } 1000 \text { mg; } \\
\text { glimepiride } 1 \mathrm{mg}\end{array}$ & $\begin{array}{c}\text { Olmesartan } 20 ; \\
\text { chlorthalidone } 12.5 \mathrm{mg}\end{array}$ & 25.7 & 7.8 \\
\hline 2 & 63 years & $\mathrm{M}$ & 4.5 years & 4 months & $\begin{array}{l}\text { Metformin } 1500 \text { mg; } \\
\text { glimepiride } 2 \text { mg }\end{array}$ & $\begin{array}{c}\text { Telmisartan 40; } \\
\text { chlorthalidone } 12.5 \mathrm{mg}\end{array}$ & 26.9 & 7.7 \\
\hline 3 & 60 years & $\mathrm{M}$ & 4 years & 2 months & $\begin{array}{l}\text { Metformin } 2000 \text { mg; } \\
\text { glimepiride } 2 \text { mg }\end{array}$ & $\begin{array}{c}\text { Amlodipine 5; } \\
\text { chlorthalidone } 12.5 \mathrm{mg}\end{array}$ & 27 & 8.1 \\
\hline 4 & 65 years & $\mathrm{M}$ & 5 years & 2 months & $\begin{array}{l}\text { Metformin } 2000 \text { mg; } \\
\text { teneligliptin } 20 \text { mg; } \\
\text { glimepiride } 1 \mathrm{mg}\end{array}$ & Chlorthalidone $12.5 \mathrm{mg}$ & 28.8 & 7.3 \\
\hline 5 & 60 years & $\mathrm{F}$ & 2 years & 3 months & $\begin{array}{l}\text { Metformin } 1500 \text { mg; } \\
\text { glimepiride } 2 \mathrm{mg}\end{array}$ & $\begin{array}{l}\text { Amlodipine } 5 ; \\
\text { chlorthalidone } 12.5 \mathrm{mg}\end{array}$ & 25.3 & 7.4 \\
\hline
\end{tabular}

the thiazide-like diuretic hydrochlorothiazide [2, 3]. There is a decrease in blood pressure of $\sim 1 \mathrm{~mm} \mathrm{Hg}$ with the loss in body weight by $1 \mathrm{~kg}$ [4]. In recent times SGLT2Is are widely used to control glycemia along-with many other parameters as they have shown multiple benefits including reduction in nephropathy and hypertension. Amongst the SGLT2Is marketed presently in India, remogliflozin is the newest one to get approval for diabetes control in type 2 diabetes. The data of remogliflozin in blood pressure reduction is sparse as the molecule is in its nascent state. Dobbins et al. in their study have shown that administration of remogliflozin etabonate for 12 days leads to clinically significant improvements in plasma glucose as well as changes in body weight and blood pressure in type 2 diabetic patients [5]. This case series is the first of its kind from India demonstrating the marked reduction in SBP, DBP and MAP when remgoliflozin etabonate $200 \mathrm{mg}$ is co-prescribed with anti-hypertensive druges.

\section{Case series presentation}

There were five type 2 diabetic patients (after taking proper written informed consent) who had a baseline ambulatory blood pressure monitoring (ABPM) report as well as ABPM report done after two weeks available. All of the patients were put on antihypertensive drugs three days prior to recording the baseline ABPM to see the dipping status of each patient and again the ABPM machine was re-installed after fourteen days of initiating remogliflozin $200 \mathrm{mg}$ to see the final outcome of antihypertensive therapy and diurnal variation after drug initiation. Baseline characters of the patients and the drugs used are depicted in Table 1 who were all put on remogliflzoin $200 \mathrm{mg}$ per day (BID).

\section{Methods}

Informed consent was taken from all the participants. All protocols were followed as per declaration laid down in the Declaration of Helsinki.

\section{Statistical analysis}

We analysed the clinic data record of the author of five selected type 2 diabetic patients with hypertension who were recently put on antihypertensive drugs and three days after starting it, each one was put on remogliflozin etabonate $200 \mathrm{mg}$. We used paired t test for comparison between the baseline and posttreatment values of ABPM for each individual. We took a $p$ value of $<0.05$ as statistically significant.

\section{Results}

This case series showed a reduction in SBP, DBP and a statistically significant drop in MAP after computing the results in paired t-test (Table 2). The $p$-value of mean changes in SBP during day time was 0.0541, p-value of mean changes in SBP during night time was 0.7828 , p-value of mean changes in DBP during day time was $0.0607, p$-value of mean changes in DBP during sleep time was 0.1533 and the change in p-value in MAP was 0.0277 which was statistically significant. The mean awake SBP showed a marked reduction with the $p$-value close to statistical significance ( $p=0.0541)$. An interesting finding of this ABPM was a change in the dipping status (Table 3) which was present in both the systolic and diastolic arms at baseline but there was not much change after treatment in the diastolic arm while it actually increased in the systolic arm making it a reverse dipping once the average is seen. The reason 
Table 2. Paired t test analysis of baseline and follow-up values of different parameters of ABPM

\begin{tabular}{lccccc}
\hline & Baseline & Follow-Up & $\begin{array}{c}\text { Absolute change } \\
\text { from baseline }\end{array}$ & 95\% Cl value \\
\hline Mean awake time SBP [mm Hg] & $129 \pm 8.09$ & $122 \pm 6.98$ & -6.8 & -13.79 to 0.19 & 0.0541 \\
Mean awake time DBP [mm Hg] & $79 \pm 6.78$ & $66.4 \pm 6.84$ & -12.6 & -26.11 to 0.91 \\
Mean sleep time SBP [mm Hg] & $123.8 \pm 14.77$ & $125.2 \pm 23.66$ & 1.4 & -11.79 to 14.59 \\
Mean sleep time DBP [mm Hg] & $72.6 \pm 10.83$ & $65.4 \pm 10.92$ & -7.2 & -18.56 to 4.16 & 0.1533 \\
MAP [mm Hg] & $94 \pm 8.37$ & $85.4 \pm 6.11$ & -8.6 & -15.66 to -1.54 & $0.0277^{*}$ \\
\hline
\end{tabular}

*Signifies statistically significant; DAB — diastolic blood pressure; SBP — systolic blood pressure; MAP — mean arterial pressure; Cl — confidence interval

Table 3. Dipping property at baseline and after follow-up

\begin{tabular}{|c|c|c|c|c|c|c|c|c|c|c|c|}
\hline $\begin{array}{l}\text { Mean } \\
\text { awake } \\
\text { SBP (B/L) }\end{array}$ & $\begin{array}{c}\text { Mean } \\
\text { sleep } \\
\text { SBP (B/L) }\end{array}$ & $\begin{array}{c}\text { Mean } \\
\text { awake } \\
\text { SBP (F/UP) }\end{array}$ & $\begin{array}{c}\text { Mean } \\
\text { sleep SBP } \\
\text { (F/UP) }\end{array}$ & $\begin{array}{c}\text { Mean } \\
\text { awake } \\
\text { DBP (B/L) }\end{array}$ & $\begin{array}{c}\text { Mean } \\
\text { sleep DBP } \\
(B / L)\end{array}$ & $\begin{array}{c}\text { Mean } \\
\text { awake DBP } \\
(\mathrm{F} / \mathrm{UP})\end{array}$ & $\begin{array}{c}\text { Mean } \\
\text { sleep DBP } \\
\text { (F/UP) }\end{array}$ & $\begin{array}{c}\% \\
\text { change } \\
\text { of SBP }\end{array}$ & $\begin{array}{c}\% \\
\text { change } \\
\text { of DBP }\end{array}$ & $\begin{array}{c}\text { Dipping } \\
\text { status } \\
\text { B/L }\end{array}$ & $\begin{array}{c}\text { Dipping } \\
\text { status } \\
\text { F/UP }\end{array}$ \\
\hline Avg & Avg & Avg & Avg & Avg & Avg & Avg & Avg & & & & \\
\hline 129 & 123.8 & 122.2 & 125.2 & 79 & 72.6 & 66.4 & 65.4 & $\begin{array}{c}\text { B/L: } 4.03 \\
\text { F/UP: } \\
-2.45\end{array}$ & $\begin{array}{c}\text { B/L: } 8.1 \\
\text { F/UP: } \\
1.5\end{array}$ & Present & $\begin{array}{c}\text { Reduced } \\
\text { but } \\
\text { present } \\
\text { for DBP } \\
\text { but lost } \\
\text { in SBP }\end{array}$ \\
\hline
\end{tabular}

Avg — average; B/L — baseline; DBP — diastolic blood pressure; SBP — systolic blood pressure; F/UP — follow-up

to it seems to come from the reading of a single patient who had a very substantial increase in his SBP and DBP readings that surpassed the reduction property seen with the others but the reason of this increase is not known (could have been any severe stress or compliance issue).

\section{Discussion}

In lower-income and developing countries we are getting an epidemic in the prevalence of obesity and type 2 diabetes (T2D) attributed to changed lifestyles with high caloric intake and low energy expenditure [6]. India has the highest prevalence of diabetes in the world mostly because of the above mentioned reasons and cheap medicines of the class of SGLT2Is are in huge demand to tackle this epidemic in India as they have multi modalities of action due to their class effect. The Sodium-Glucose Cotransporter 2 (SGLT2) Inhibitor and Angiotensin Receptor Blocker (ARB) Combination Therapy in Patients with Diabetes and Uncontrolled Nocturnal Hypertension study (SACRA) was done to investigate changes in blood pressure with existing antihypertensive therapy and empagliflozin and it showed older diabetes patients who are nonseverely obese having uncontrolled hypertension at night-time had a significant blood pressure reduction without significant reductions in glyce- mic parameter [7]. In an animal study by Nakano et al. it was seen that out of canagliflozin, dapagliflozin and remogliflozin, only remogliflozin showed a reduction in oxygen radical absorbance capacity (ORAC) as well as there was marked lowering of both serum alanine aminotransferase (76\%) and aspartate aminotransferase $(48 \%)$, and there was also reduction in hepatic triglyceride content by $40 \%$ and liver weight by $42 \%$ [8]. The use of approved SGLT2 inhibitors was associated with mean reduction of systolic and diastolic blood pressure of $4.0 \mathrm{~mm} \mathrm{Hg}$ and $1.6 \mathrm{~mm} \mathrm{Hg}$, respectively, compared with baseline [9]. This case series is the first data from Indian patients who were co-prescribed remogliflozin and antihypertensive drugs with chlorthalidone being present in all the groups showing improvements in mean SBP and mean DBP and a statistically significant reduction in MAP. There were few limitations of this case series analysis: small sample size makes it impossible to conclude that remogliflozin has potent $\mathrm{BP}$ reducing capacity as there was concomitant administration of antihypertensives; there was no chance to intervene in the lifestyle of the patients to find out the modifications they are applying themselves to correct their hypertension other than those prescribed by the author; they also did not tell the author about any illness which might have happened during the time of ABPM recording. 


\section{Conclusions}

Our case series analysis shows for the first time the possibility of significant SBP and DBP reduction with remogliflozin and antihypertensives but we need large randomised trials or larger real-world data to have a final conclusion. Till that time we can presume that remogliflozin also shares the same pleotropic benefit of $\mathrm{BP}$ reductions to some extent like shown by the existing three SGLT2Is. The significant BP reduction shown here may be a chance finding as in real-world setting the BP reductions seen with SGLT2I is much lesser than seen in this case series and hence it is mostly contributed by the antihypertensive therapy that was given.

\section{Conflict of interest}

The author declares no conflict of interest.

\section{REFERENCES}

1. de Ferranti SD, de Boer IH, Fonseca V, et al. Type 1 diabetes mellitus and cardiovascular disease: a scientific statement from the American Heart Association and American Diabetes Association. Circulation. 2014; 130(13): 1110-1130, doi: 10.1161/ CIR.0000000000000034, indexed in Pubmed: 25114208.

2. Weber MA, Bakris GL, Jamerson $\mathrm{K}$, et al. ACCOMPLISH Investigators. Cardiovascular events during differing hypertension therapies in patients with diabetes. J Am Coll Cardiol. 2010; 56(1): 77-85, doi: 10.1016/j.jacc.2010.02.046, indexed in Pubmed: 20620720.
3. Bakris G, Briasoulis A, Dahlof B, et al. ACCOMPLISH Investigators, ACCOMPLISH Trial investigators, ACCOMPLISH Trial Investigators. Benazepril plus amlodipine or hydrochlorothiazide for hypertension in high-risk patients. N Engl J Med. 2008; 359(23): 2417-2428, doi: 10.1056/NEJMoa0806182, indexed in Pubmed: 19052124.

4. Semlitsch T, Jeitler K, Berghold A, et al. Long-term effects of weight-reducing diets in people with hypertension. Cochrane Database Syst Rev. 2016; 3: CD008274, doi: 10.1002/14651858. CD008274.pub3, indexed in Pubmed: 26934541.

5. Dobbins RL, O'Connor-Semmes R, Kapur A, et al. Remogliflozin etabonate, a selective inhibitor of the sodium-dependent transporter 2 reduces serum glucose in type 2 diabetes mellitus patients. Diabetes Obes Metab. 2012; 14(1): 15-22, doi: 10.1111/j.1463-1326.2011.01462.x, indexed in Pubmed: 21733056.

6. Petrie JR, Guzik TJ, Touyz RM. Diabetes, Hypertension, and Cardiovascular Disease: Clinical Insights and Vascular Mechanisms. Can J Cardiol. 2018; 34(5): 575-584, doi: 10.1016/j.cjca.2017.12.005, indexed in Pubmed: 29459239.

7. Kario K, Okada K, Kato M, et al. Twenty-Four-Hour Blood Pressure-Lowering Effect of a Sodium-Glucose Cotransporter 2 Inhibitor in Patients With Diabetes and Uncontrolled Nocturnal Hypertension. Circulation. 2019; 139(18): 2089-2097, doi: 10.1161/ circulationaha.118.037076.

8. Nakano S, Katsuno K, Isaji M, et al. Remogliflozin Etabonate Improves Fatty Liver Disease in Diet-Induced Obese Male Mice. J Clin Exp Hepatol. 2015; 5(3): 190-198, doi: 10.1016/j. jceh.2015.02.005, indexed in Pubmed: 26628836.

9. Baker WL, Smyth LR, Riche DM, et al. Effects of sodium-glucose co-transporter 2 inhibitors on blood pressure: a systematic review and meta-analysis. J Am Soc Hypertens. 2014; 8(4): 262-75.e9, doi: 10.1016/j.jash.2014.01.007, indexed in Pubmed: 24602971. 